\title{
La Revista de Derecho y el detrás de su edición
}

María Paula Garat

ORCID: 0000-0001-8452-5338

Universidad Católica del Uruguay

Correo: maria.garat@ucu.edu.uy

Junto con esta Editorial se publica el número 24 de la Revista de Derecho de la Universidad Católica del Uruguay. Desde el año 2019 tuve la grata oportunidad de incorporarme como editora científica de esta revista y, siendo este ya el cuarto número en cuya edición participo, me parece oportuno -y necesario- hacer mención al gran trabajo que hay detrás de su edición.

Cuando leemos, consultamos o citamos un artículo de una revista científica difícilmente reparemos en todo el trabajo que hay detrás: las convocatorias, la recepción de artículos, el análisis técnico, el antiplagio, la revisión científica, los plazos. En las revistas arbitradas - como esta- se le adiciona la revisión por pares, la búsqueda de árbitros, las aceptaciones, las sugerencias y observaciones, los rechazos, los nuevos envíos, entre tantas otras.

Como académica el trabajo es gratificante. El poder estar en la cocina de la producción y difusión científica, el apoyar a los autores y autoras a mejorar sus postulaciones y el ser parte del proceso es una tarea que para algunos será engorrosa, para otros -en los que me incluyo- es verdaderamente satisfactoria. Especialmente cuando luego de un largo proceso que insume meses el artículo es finalmente aceptado para su publicación, la satisfacción final es más que merecedora de todo el trabajo realizado.

En este contexto, y en esta Editorial, entiendo oportuno destacar tres puntos importantes del detrás de este número de la Revista de Derecho. Por una parte, el destacado trabajo de edición técnica que con gran entrega y profesionalidad realiza el Centro de Publicaciones de la Universidad, a través de las editoras técnicas de esta revista. Por otra parte, el también destacado trabajo con el que este número contó de Joaquín Otormín, un estudiante de segundo año de Abogacía, a quien le interesó este detrás de la revista y se embarcó en la ayuda a la edición científica como colaborador honorario. En tercer lugar, el proyectado homenaje que en este y en el próximo número se concreta, a 75 años de la Ley n. ${ }^{\circ} 10.783$ del 18 de setiembre de 1946, denominada Ley de Derechos Civiles de la Mujer. 
Por esto último, nos propusimos recibir artículos sobre la temática y varios autores y autoras han enviado sus postulaciones. Algunas son publicadas en este número y otras lo serán en el siguiente. Les siguen a estas páginas, una Editorial especial de la Prof. Beatriz Ramos en atención a esta conmemoración.

Además de ello, este número cuenta con otros artículos, también de elevada calidad, que enriquecen la producción científica en el derecho, de autores y autoras nacionales e internacionales, y de distintas temáticas.

Todo lo anterior, que implica un gran trabajo, son algunos de los aspectos que están en este detrás de su edición.

Dra. María Paula Garat 